\title{
New Hyphessobrycon from the upper rio Pardo drainage in eastern Brazil (Teleostei: Characiformes: Characidae)
}

\author{
Vinicius A. Bertaco*, Luiz R. Malabarba*,** and Jorge A. Dergam***
}

A new species of characid, Hyphessobrycon vinaceus, is described from the upper rio Pardo, Minas Gerais, Brazil. The new species is distinguished from all other Hyphessobrycon species by the combination of the following characters: the body red or reddish pigmented in live specimens, an anterior and conspicuous vertically elongate black humeral spot followed by a second faint humeral spot, 5 teeth in the inner series of premaxilla, maxilla with 2-3 pentacuspidate teeth, 15-17 branched analfin rays, 4-5 scale rows above and 3-4 scale rows below lateral line, lateral line with 10-26 perforated scales, 32-34 scales in a longitudinal series, and by a smaller head length in relation to standard length (23.9-26.7\%).

Uma nova espécie de caracídeo, Hyphessobrycon vinaceus é descrita para o alto rio Pardo, Minas Gerais, Brasil. A nova espécie distingue-se das demais espécies de Hyphessobrycon pela combinação dos seguintes caracteres: coloração avermelhada do corpo em vida, uma mancha umeral preta e conspícua verticalmente alongada seguida de uma segunda mancha umeral fracamente pigmentada, 5 dentes na série interna do pré-maxilar, 2-3 dentes pentacuspidados no maxilar, 15-17 raios ramificados na nadadeira anal, 4-5 escamas acima e 3-4 escamas abaixo da linha lateral, 10-26 escamas perfuradas na linha lateral, 32-34 escamas em uma série longitudinal e menor comprimento da cabeça em relação ao comprimento padrão (23,9-26,7\%).

Key words: Hyphessobrycon hamatus, Taxonomy, Fin hooks, Sexual dimorphism.

\section{Introduction}

Hyphessobrycon is a speciose genus of the family Characidae including more than 100 valid species (Lima et al., 2003; Bertaco \& Carvalho, 2005) distributed from southern Mexico to río de La Plata in Argentina. The genus was proposed by Durbin in Eigenmann (1908:100) as a subgenus of Hemigrammus Gill, differing from the latter by the absence of scales on the caudal-fin. Hyphessobrycon was revised by Eigenmann $(1918,1921)$ whose accounts still constitute the single comprehensive review of the then known members of the genus. The recognition of groups of species in the genus is based primarily on similarities of color patterns (Géry, 1961, 1966, 1977). Weitzman \& Palmer (1997) hypothesized the existence of a monophyletic group of Hyphessobrycon species, based on the coloration pattern and the shape of the dorsal and anal fins of males that they termed the rosy tetra clade. However, those authors did not present a hypothesis for the resolution of the relationships of the remaining species in Hyphessobrycon.

A new species of Hyphessobrycon was discovered during a recent collection made by JAD in headwater streams of the upper rio Pardo drainage, that is described below. The rio Pardo is an eastern coastal drainage with its upper and middle portions located in the state of Minas Gerais and its lower stretch in the state of Bahia, within the domain of the Atlantic forest. Fish species recently described from this area are Simpsonichthys rosaceus Costa, Nielsen \& de Luca, S. suzarti Costa (Rivulidae), and Astyanax pelecus Bertaco \& Lucena (Characidae).

\section{Materials and Methods}

Counts were taken as described by Fink \& Weitzman (1974) with the exception of the number of scale rows below the lateral line that was counted from the scale row ventral to the

\footnotetext{
*Museu de Ciências e Tecnologia, Pontifícia Universidade Católica do Rio Grande do Sul, Av. Ipiranga 6681, 90619-900 Porto Alegre, RS, Brazil.ubertaco@pucrs.br

**Departamento de Zoologia, IB, Universidade Federal do Rio Grande do Sul, Av. Bento Gonçalves, 9500, $91501-970$ Porto Alegre, RS, Brazil.malabarb@ufrgs.br

***Departamento de Biologia Animal, Universidade Federal de Viçosa, Av. P. H. Rolfs s/n, 36570-000 Viçosa, MG, Brazil. dergam@ufv.br
} 
lateral line to the scale row closest to the pelvic-fin insertion. Counts of vertebrae supraneurals, gill-rakers, teeth and procurrent caudal-fin-rays were taken from cleared and stained specimens (c\&s) prepared according to the method of Taylor $\&$ Van Dyke (1985). Tooth counts were also taken in all type specimens. Counts of the holotype are given first followed in parentheses by the mean and total number of specimens counted. Vertebral counts include the four vertebrae integrated in the Weberian apparatus, and the terminal centrum was counted as one vertebra. Statistical tests of differences between the sexes were performed. Scanning electronic micrographs (SEM) of teeth and jaws were taken from one dissected cleared and stained specimen.

Measurements were taken point to point with an electronic caliper on the left side of the specimens. All measurements other than SL are expressed as percentages of SL except for subunits of the head that are recorded as percentages of head length (HL).

The examined specimens are deposited at the California Academy of Sciences, San Francisco (CAS), Museu de Ciências e Tecnologia, Pontifícia Universidade Católica do Rio Grande do Sul, Porto Alegre (MCP), and Museu de Zoologia da Universidade de São Paulo, São Paulo (MZUSP).

\section{Hyphessobrycon vinaceus, new species}

Figs. 1 and 2

Holotype. MCP 40916, 56.5 mm SL, male; Brazil, Minas Gerais, São João do Paraíso, rio São João, tributary of the upper rio Pardo, $15^{\circ} 09^{\prime} 50^{\prime \prime S} 42^{\circ} 09^{\prime} 45^{\prime} \mathrm{W}, 26$ Apr 2006, J. A. Dergam \& A. A. Oliveira.

Paratypes. MCP 40141, 6 (2 males, 46.7-54.1 mm SL; 1 male c\&s $46.7 \mathrm{~mm}$ SL; 4 females, 56.1-62.8 mm SL; 1 female c\&s $49.6 \mathrm{~mm}$ SL), MZUSP 94439, 3 (1 male, 56.3 mm SL; 2 females, 48.3-56.9 $\mathrm{mm}$ SL), collected with the holotype; MCP 40915 (3 males, 51.0$54.0 \mathrm{~mm} \mathrm{SL}$ ), same data of the holotype; these specimens were kept in aquarium for one year.

Diagnosis. Hyphessobrycon vinaceus is distinguished from all other species of Hyphessobrycon except of H. melanos- tichos Carvalho \& Bertaco, H. notidanos Carvalho \& Bertaco, and the species of the 'rosy tetra clade' Weitzman \& Palmer (1997), by the red or reddish pigmented body in live specimens. Hyphessobrycon vinaceus differs from the species included in the 'rosy tetra clade' in the number of teeth in the inner row of the premaxilla ( 4 or $5 v s 7$ to 12), and in the number of branched anal-fin rays (15-17 vs 22-29); it differs from $H$. melanostichos by the absence of a conspicuous longitudinal broad black band beginning on the posterior margin of orbit and reaching the tip of middle caudal fin rays; from $H$. notidanos by the lack of an elongated dorsal fin in mature males, in the number of dorsal-fin rays (ii, $9 v s$ iii, 8), and number of perforated lateral-line scales (10-26 vs 6-9).

Description. Morphometric data summarized in Table 1. Body compressed and moderately deep; greatest body depth anterior to dorsal-fin origin. Dorsal head profile straight or slightly convex. Dorsal body profile convex from supraoccipital tip to base of last dorsal-fin ray, and straight from that point to adipose-fin origin. Ventral profile of head convex. Ventral profile of body convex from pectoral-fin origin to anal-fin origin. Body profile along anal-fin base straight and posterodorsally slanted. Caudal peduncle elongate, nearly straight to slightly concave along both dorsal and ventral margins.

Snout rounded from margin of upper lip to vertical through anterior nostrils. Mouth terminal. Maxilla extending posteriorly to under middle of orbit, slightly curved, and aligned at approximately 45 degrees angle relative to longitudinal axis of body. Anterodorsal border of maxilla concave, posterodorsal border slightly convex, anteroventral border concave, and posteroventral border convex. Maxilla slightly widened posteriorly.

Premaxilla with two tooth rows; outer row with 2-4, tricuspid or pentacuspid teeth with central cusp longer; inner row 5 (one with 4) teeth with 5-7 cusps and central cusp longer and broader than other cusps, inner row teeth gradually decreasing in length from first to fourth teeth, last tooth considerably smaller. Two to three maxillary teeth, with 5 cusps, central

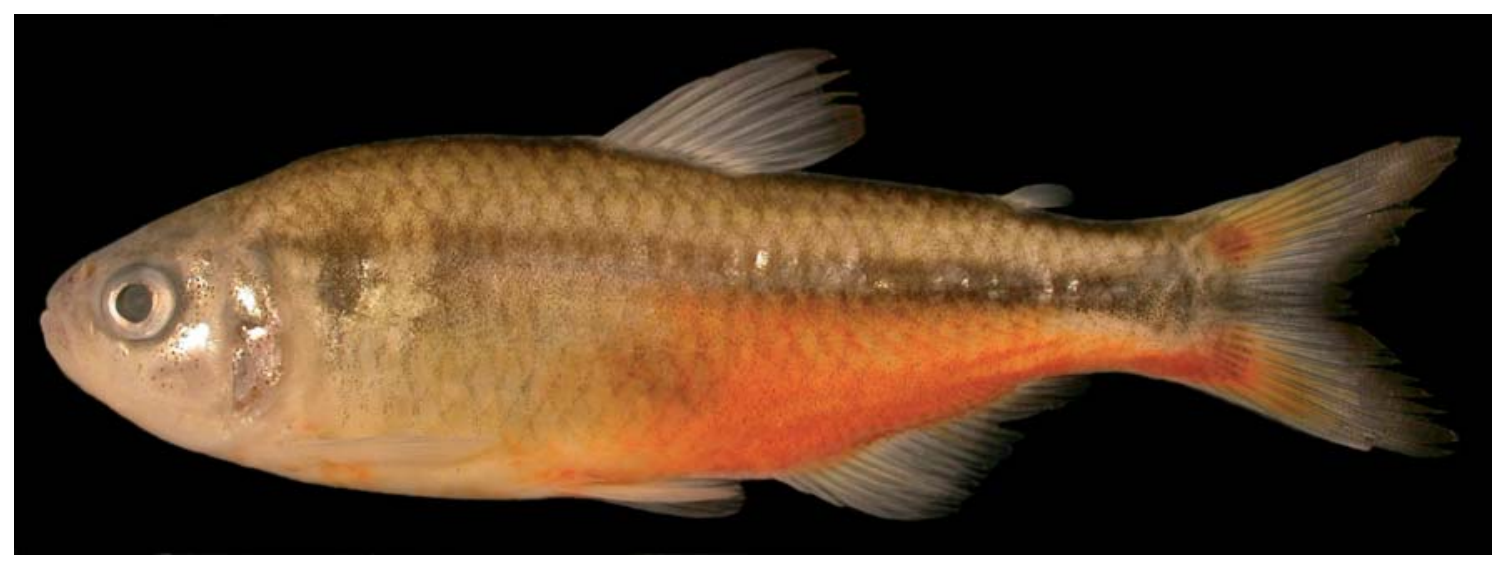

Fig. 1. Hyphessobrycon vinaceus, MCP 40916, holotype, male, 56.5 mm SL; Brazil, Minas Gerais, São João do Paraíso, rio São João, tributary of upper rio Pardo. 
cusp slightly longer. Four or 5 anteriormost dentary teeth larger, with 5-7 cusps, followed by medium sized tooth with 5 cusps, and 5-6 smaller teeth with 1-3 cusps or conical; central cusp in all teeth two to three times longer and broader than remaining cusps. Cusp tips slightly curved posteriorly and lingually (Fig. 2).

Scales cycloid, moderately large. Lateral line incomplete, perforated scales 10-26 $(26$, mean $=16, \mathrm{n}=12)$. Longitudinal scale series including lateral-line scales 32-34 (34, mean $=$ $33.1, \mathrm{n}=12)$. Scale rows between dorsal-fin origin and lateral line $5(5$, one with 4 , mean $=4.9, \mathrm{n}=12)$; scale rows between lateral line and pelvic-fin origin 3-4 $(4$, mean $=3.6, \mathrm{n}=12)$. Predorsal scales 11-12, arranged in regular series $(11$, mean $=$ $11.7, n=12)$. Scales rows around caudal peduncle $14(n=12)$. Scale sheath along anal-fin base with 3-5 scales in single series $(5, n=12)$, extending posteriorly to base of first rays.

Dorsal-fin rays ii,9 $(n=13)$; first unbranched ray approximately one-half length of second ray. Males with small bony hooks in distal one-third of first to fifth branched rays. Dorsal-fin origin located approximately at middle of SL and posterior to vertical through pelvic-fin origin. Adipose-fin located approximately at vertical through insertion of $13^{\text {th }}$ $15^{\text {th }}$ branched anal-fin rays. Anal-fin rays iii-iv, 15-17 (iii, 16, mean $=16.1, \mathrm{n}=13$ ). First unbranched ray usually only apparent in cleared and stained specimens. Anal-fin profile smoothly concave in females and nearly straight in males. Anal-fin origin located posterior to vertical through base of last dorsal-fin ray. Anal-fin rays of males bearing one pair of retrorse bony hooks along posterolateral border of each segment of lepidotrichia, usually along last unbranched ray and fifteen anterior branched rays; hooks more numerous along first through tenth branched rays. Hooks usually located along posteriormost branch and distal $1 / 2$ to $2 / 3$ length of each ray. Pectoral-fin rays i,9-12 (i,9, mean $=11.3, \mathrm{n}=13)$.

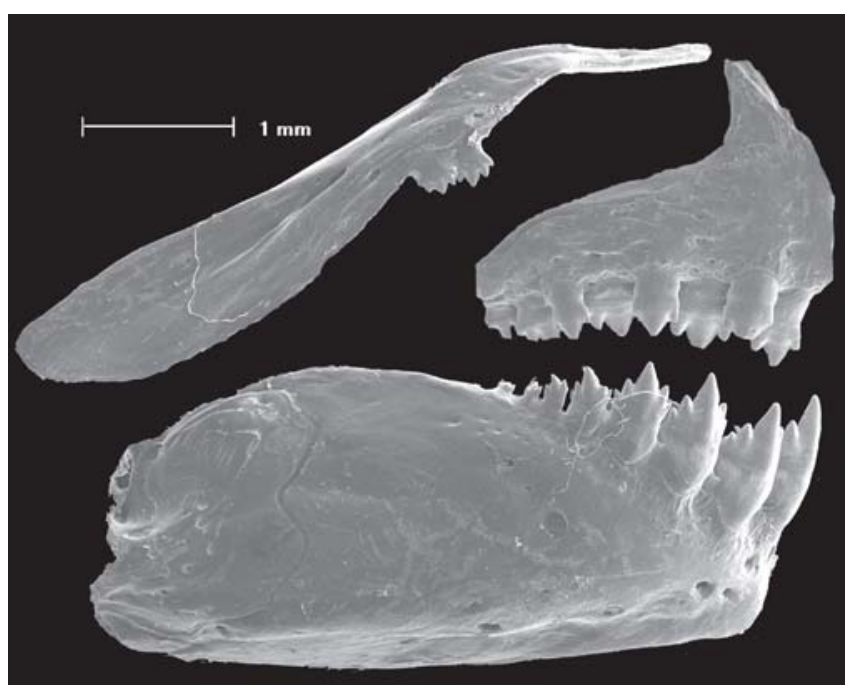

Fig. 2. Scanning electronic micrograph of upper and lower jaws (right side) of Hyphessobrycon vinaceus, MCP 40141, paratype, female, $49.6 \mathrm{~mm} \mathrm{SL}$.
Males with small bony hooks on distal portion of first to fifth branched rays. Pelvic-fin rays i, 7 (one with i,6,i, $n=13$ ). Pelvicfin origin located anterior to vertical through dorsal-fin origin. Pelvic fin of males usually bearing small bony hooks along ventromedial border of second to third branched rays. Caudalfin forked, with 19 principal rays with small bony hooks at tip of middle caudal-fin rays. Dorsal procurrent rays 10, and ventral procurrent rays $9(n=2)$.

Precaudal vertebrae 16; caudal vertebrae 16-17; total vertebrae 32-33. Supraneurals 5. Gill-rakers 6/10 $(n=2)$.

Color in alcohol. Dorsal and dorsolateral portions of head and body dark brown. Infraorbital and opercular areas covered with scattered, dark chromatophores. Scales on lateral and ventral surface of body bordered with dark brown chromatophores forming a reticulate color pattern. Dark anterior humeral spot vertically-elongate, and narrowing ventrally, located over second to fourth lateral-line scales and extending over 4-5 horizontal series of scales including lateral line. Second humeral spot diffuse, located nearly above $7^{\text {th }}-8^{\text {th }}$ lateral line scale and at anterior end of midlateral stripe, and extending usually over two horizontal series of scales above lateral line. Faint midlateral body stripe extending from second humeral spot to tip of median caudal-fin rays, gradually wider and more intensely pigmented towards caudal peduncle. Midlateral body stripe slightly wider on caudal peduncle and caudal-fin base forming small spot. Fins with scattered dark chromatophores (Fig. 1). Some specimens examined soon after fixation in formalin with ventrolateral portion of body, and caudal fin base with intensely red-orange or reddish coloration. Males and females with similar color pattern.

Color in life. Color pattern similar to that described for alcohol preserved specimens except as follows. Body dorsal portion

Table 1. Morphometric data of holotype (MCP 40916) and paratypes (MCP 40141; MZUSP 94439) of Hyphessobrycon vinaceus from the upper rio Pardo drainage $(\mathrm{n}=10$ including the holotype). $\mathrm{SD}=$ standard deviation.

\begin{tabular}{lcccc}
\hline & Holotype & Range & Mean & SD \\
\hline Standard length (mm) & 56.5 & $46.7-62.8$ & 55.0 & - \\
\multicolumn{5}{c}{ Percents of standard length } \\
Predorsal distance & 50.0 & $50.0-55.8$ & 52.6 & 1.55 \\
Prepelvic distance & 47.2 & $46.9-49.9$ & 48.3 & 1.12 \\
Prepectoral distance & 24.6 & $24.2-26.5$ & 25.4 & 0.77 \\
Preanal distance & 65.2 & $65.2-69.4$ & 67.0 & 1.45 \\
Depth at dorsal-fin origin & 31.4 & $30.1-35.8$ & 32.1 & 1.82 \\
Caudal peduncle depth & 12.8 & $11.4-13.5$ & 12.8 & 0.60 \\
Caudal peduncle length & 16.4 & $14.9-17.4$ & 15.9 & 0.74 \\
Anal-fin base & 22.8 & $20.7-25.1$ & 22.2 & 1.39 \\
Dorsal-fin length & 22.9 & $22.4-24.2$ & 23.2 & 0.56 \\
Pelvic-fin length & 16.2 & $15.1-17.1$ & 16.3 & 0.63 \\
Pectoral-fin length & 19.7 & $18.9-21.7$ & 20.0 & 0.85 \\
Head length & 24.1 & $23.9-26.7$ & 25.2 & 1.04 \\
& \multicolumn{5}{c}{ Percents of head length } \\
Snout length & 23.8 & $21.1-25.8$ & 23.8 & 1.37 \\
Upper jaw length & 41.3 & $39.6-47.2$ & 43.3 & 2.47 \\
Orbital diameter & 27.5 & $24.2-31.4$ & 27.9 & 2.05 \\
Interorbital width & 34.8 & $32.1-36.7$ & 34.7 & 1.21 \\
\hline
\end{tabular}


green to gray brown. Abdomen and opercle portions silvery to brilliant green. Body portion above anal-fin base, and pectoral, pelvic, and anal fins intensely red or reddish pigmented. Dorsal and caudal fins green or yellowish brown. Red or reddish coloration is more evident in freshly preserved specimens in formalin.

Sexual dimorphism. Males of $H$. vinaceus are easily recognized by the presence of bony hooks on all fin rays, observed in males larger than $46.7 \mathrm{~mm}$ SL. Males and females also slightly differ in anal-fin shape, which is concave in females and nearly straight in males. One male and female (46.7 and $49.6 \mathrm{~mm} \mathrm{SL}$ ) were dissected before clearing and staining, and only the male had mature gonads. Gill glands were not found on first gill arch in both males and females.

Distribution. Hyphessobrycon vinaceus is known only from rio São João, in the headwaters of the rio Pardo drainage, a coastal drainage in eastern Brazil.

Etymology. The specific name vinaceus is from Latin and means reddish, and it is in allusion to the body coloration red or reddish observed in live specimens.

Ecological notes. At the type locality, the rio São João is a fast running clear water and shallow river about four to five meters wide, with sandy bottom, and large amount of riparian vegetation. Live specimens of $H$. vinaceus were caught in rapid stretches just below a small waterfall. Hyphessobrycon vinaceus was collected syntopically with Aspidoras cf. albater and Otothyropsis sp.

\section{Discussion}

Hyphessobrycon vinaceus is included in this genus according to the definition, proposed by Durbin in Eigenmann (1908) and further elaborated by Eigenmann (1918): premaxillary teeth in two rows; maxillary teeth absent or reduced in number and restricted to the upper portion of its free margin; lateral line incomplete; adipose fin present and caudal fin naked.

The intensely red or reddish pigmented ventrolateral portion of body and caudal fin base in live specimens of $H$. vinaceus easily distinguish the new species from most Hyphessobrycon species. Similarities with H. melanostichos, $H$. notidanos and some species of the 'rosy tetra clade' remains only in the presence of reddish pigments but $H$. vinaceus is easily distinguished from those species by the characters listed in the diagnosis.

Mature males of $H$. vinaceus possess bony hooks on rays of all fins. Gonçalves et al. (2005) observed a positive correlation between mean gonadosomatic index of maturing and mature males and the number of anal-fin rays bearing hooks in Aphyocharax anisitsi, and suggested these hooks develop along with sexual maturation, and once developed are retained by the males. The presence of hooks on fin rays was proposed as a synapomorphy for a group containing most genera and subfamilies of the Characidae (Malabarba \& Weitzman, 2003), but these hooks are usually found only in the anal- and pelvic-fin rays and sometimes in the caudal-fin rays of males, and usually represent a secondary sexual character. However, the occurrence of bony hooks in all fins, including dorsal, caudal, and pectoral fins in males is uncommon in characids. Some recently described species of Tetragonopterinae (sensu Géry) also possess bony hooks on rays of all fins in males, e.g. Astyanax ojiara and Moenkhausia pankilopteryx, and in all fins except the caudal fin, e.g. A. elachylepis and H. hamatus (see Bertaco \& Lucinda, 2006). Among Hyphessobrycon species, the presence of bony hooks on the dorsal-fin rays is known to occur only in $H$. socolofi, H. erythrostigma (see Weitzman, 1977), H. hamatus and $H$. uruguayensis (Fowler) (pers. obs.). Hyphessobrycon vinaceus differs from $H$. socolofi and $H$. erythrostigma by number of branched anal-fin rays (15-17 vs 28-30 and 27-29, respectively), and by absence of a black spot on dorsal fin $v$ s the presence of such pigmentation; from $H$. hamatus by head length (23.9-26.7 vs 27.5-32.3\% of SL), caudal peduncle length (14.9-17.4 vs 10.0-14.4\% of SL), and orbital diameter (24.2-31.4 vs 29.1-33.7\% of HL); and from H. uruguayensis by maxillary teeth (1-3 vs 6-11), branched anal-fin rays (15-17 vs 20-26), and absence of black longitudinal lines in the lateral body $v s$ presence.

Hyphessobrycon vinaceus possesses dark chromatophores delineating the scale borders over the body, a character found in $H$. balbus Myers, $H$. langeanii Lima \& Moreira, $H$. boulengeri (Eigenmann), and H. hamatus (see discussion in Bertaco \& Malabarba, 2005). Hyphessobrycon vinaceus further shares some characters with H. hamatus not found in other species of the genus as the larger number of perforated scales, reduced number of anal-fin rays, and presence of bony hooks on all fins, except the caudal fin in H. hamatus. The general lack of knowledge of the relationships within Hyphessobrycon, however, precludes further inferences on the possible relationships among these species based on these characters.

Comparative material. Hyphessobrycon balbus: CAS 60463, 15 paratypes, lagoa Fervedeira, Planaltina, Goiás, Brazil. Hyphessobrycon boulengeri: MCP 21685, 11, channel between lagoa Emboaba and Emboabinha, Osório, Rio Grande do Sul, Brazil. Hyphessobrycon hamatus: MCP 34000, holotype, $43.1 \mathrm{~mm}$ SL, MCP 33930, 10 paratypes, 26.7-44.8 mm SL, tributary of rio Vermelho, rio Tocantins drainage, Mambaí, Goiás, Brazil. Hyphessobrycon uruguayensis, MCP 36795, 13, arroyo Salsipuedes, río Negro drainage, Tacuarembó, Uruguay.

\section{Acknowledgments}

We are grateful to the Centro de Microscopia e Microanálises - CEMM, PUCRS for the SEM preparations, to Alexandre Charcansky and Tiago Carvalho (MCP) for helping with the preparation of figure 2, and David Catania (CAS) for the loan of specimens. Thanks are also due to Pablo 
Lehmann for the photograph of specimens of Hyphessobrycon vinaceus taken just after fixation. VAB is financially supported by the Coordenação de Aperfeiçoamento de Pessoal de Nível Superior (CAPES), and LRM by the Conselho Nacional de Desenvolvimento Científico e Tecnológico (CNPq, Proc. 476821/2003-7; Proc. 478002/2006-8).

\section{Literature Cited}

Bertaco, V. A. \& T. P. Carvalho. 2005. A new characid fish, Hyphessobrycon hexastichos (Characiformes: Characidae) from Chapada dos Parecis, Mato Grosso, Brazil. Neotropical Ichthyology, 3(3): 439-443.

Bertaco, V. A. \& L. R. Malabarba. 2005. A new species of Hyphessobrycon (Teleostei: Characidae) from the upper rio Tocantins drainage, with bony hooks on fins. Neotropical Ichthyology, 3(1): 83-88.

Bertaco, V.A. \& P. H. F. Lucinda. 2006. Moenkhausia pankilopteryx, new species from rio Tocantins drainage, Brazil (Ostariophysi, Characiformes, Characidae). Zootaxa, 1120: 57-68.

Eigenmann, C. H. 1908. Zoological results of the Thayer Brazilian Expedition. Preliminary descriptions of new genera and species of Tetragonopterid characins. Bulletin of the Museum of Comparative Zoology, 52(6): 93-106.

Eigenmann, C. H. 1918. The American Characidae. Part 2. Memoirs of the Museum of Comparative Zoology, 43: 103-208.

Eigenmann, C. H. 1921. The American Characidae. Part 3. Memoirs of the Museum of Comparative Zoology, 43: 209-310.

Fink, W. L. \& S. H. Weitzman. 1974. The so-called Cheirodontin fishes of Central America with descriptions of two new species (Pisces: Characidae). Smithsonian Contributions to Zoology, 172: 1-46.

Géry, J. 1961. Three new South American characids, Knodus savannensis, Hyphessobrycon herbertaxelrodi and Megalamphodus sweglesi, with a review of some Hyphessobrycon-groups of species (Contr. No. 16). Tropical Fish Hobbyist, 9(9): 26-46.
Géry, J. 1966. Hyphessobrycon vilmae sp. n., a new tetra from the upper Juruena, Brazil, with keys to the Heterorhabdus-like species. Ichthyologica/The Aquarium Journal, 63-70.

Géry, J. 1977. Characoids of the World. T.F.H. Publications, Neptune City, NJ, 672p.

Gonçalves, T. K., M. A. Azevedo, L. R. Malabarba \& C. B. Fialho. 2005. Reproductive biology and development sexually dimorphic structures in Aphyocharax anisitsi (Ostariophysi: Characidae). Neotropical Ichthyology, 3(3): 433-438.

Lima, F. C. T, L. R. Malabarba, P. A. Buckup, J. F. Pezzi da Silva, R. P. Vari, A. Harold, R. Benine, O. T. Oyakawa, C. S. Pavanelli, N. A. Menezes, C. A. S. Lucena, M. C. S. L. Malabarba, Z. M. S. Lucena, R. E. Reis, F. Langeani, L. Casatti, V. A. Bertaco, C. Moreira \& P. H. F. Lucinda. 2003. Genera incertae sedis in Characidae. Pp. 134-141. In: R. E. Reis, S. O. Kullander \& C. J. Ferraris (Eds.). Check List of the Freshwater Fishes of South and Central America. Porto Alegre, Edipucrs, 729p.

Malabarba, L. R. \& S. H. Weitzman. 2003. Description of new genus with six new species from southern Brazil, Uruguay and Argentina, with a discussion of a putative characid clade (Teleostei: Characiformes: Characidae). Comunicações do Museu de Ciências e Tecnologia da PUCRS, Série Zoologia, 16(1): 67-151.

Taylor, W. R. \& G. C. Van Dyke. 1985. Revised procedures for staining and clearing small fishes and other vertebrates for bone and cartilage study. Cybium, 9:107-119.

Weitzman, S. H. 1977. Hyphessobrycon socolofi, a new species of characoid fish (Teleostei: Characidae) from the Rio Negro of Brazil. Proceedings of the Biological Society of Washington, 90(2): 326-347.

Weitzman, S. H. \& L. Palmer. 1997. A new species Hyphessobrycon (Teleostei: Characidae) from the Neblina region of Venezuela and Brazil, with comments on the putative 'rosy tetra clade'. Ichthyological Exploration of Freshwaters, 7(3): 209-242.

Submitted January 2007 Accepted July 2007 